\title{
HAVNEN OG DET HETEROGENE BYRUM NORDHAVN BETRAGTET GENNEM GEORGES BATAILLES HETEROLOGI
}

Nordhavn i København er stedet for næste etape i revitaliseringen af de københavnske havnefronter. Den snarligt afviklede industrihavn står over for at blive kapitaliseret som gennemdesignet boligområde, hvad der står i stærk kontrast til de nuværende havnearealers rå industrielle og ikke-planlagte karakter. Nordhavn udgør dermed et aktuelt skalastudie i de omdannelsesprocesser, som Københavns havn - i lighed med resten af den vestlige verdens havnebyer - har gennemgået i løbet af de sidste årtier. Denne proces, hvor de funktionstømte havnearealer gennemgår en økonomisk, arkitektonisk, kulturel og social transformation, forandrer havnens interurbane status fra overset bagside til eksponeret forside. Postindustrialismens havnefronter er blevet særdeles attraktive byrum og et vigtigt forum for den kontemporære bys æstetiske så vel som økonomiske og sociale værdisætning. Havnen opfattes som byens nye ansigt udadtil og stedet, hvor diskussion om det gode byrum folder sig ud. I denne debat høres ofte argumentet om det mangfoldige - et begreb, der ligeledes fremhæves i planlægningsforløbet, men lige så ofte udgør omdrejningspunktet i kritikken, når det færdige byrum beskyldes for at mangle de umiddelbare, uforudsigelige og uafsluttede fortællinger, der kendetegner et vitalt og værdipluralt byrum.

En tendens i bestræbelserne på at undgå urban ensretning peger derfor i stigende grad på integrationen af noget fremmedartet, ikke-planlagt og midlertidigt i planlægningsprocessen: Et paradigmeskifte, der i relation til havnefronternes omdannelser sætter fornyet fokus på kvaliteter og potentialer ved den industrielle og funktionstømte havn, som den tager sig ud forud for omdannelsesprocesserne.

Spørgsmålet om det fremmedartedes tilstedeværelse i byens rum udgør rammen for foreliggende læsning af Nordhavn med udgangspunkt $i$ den franske filosof Georges Batailles begreb om det heterogene. For selvom Batailles heterologi ikke er lavet med specifikt henblik på en bykulturel tematik, rummer denne tænkning om tilværelsens heterogene fænomener en række perspektiver, der synes brugbare i relation til den postindustrielle bys omdannelsesprocesser og diskussionen om det fremmedartedes betydning for bymæssig diversitet. 


\section{Begrebet om det radikalt anderledes}

Georges Batailles heterologi - "The science of what is completely other" (Bataille, "The Use Value of D.A.F. De Sade" IO2) - lanceres i I920'erne som en marxistisk, sociologisk og psykoanalytisk inspireret civilisationskritik af periodens rationelle ensretning og fremvoksende fascisme. Med denne formulerer Bataille et radikalt alternativ, der modsat samtidens politiske og sociale idealer tager udgangspunkt $\mathrm{i}$ tilværelsens irrationelle og nedre sider, dvs. alt det, der opfattes som nytteløst og urent. Det radikalt anderledes skal således forstås som alle de elementer og begivenheder fra vores samfund, dagligdag, krop og eksistens, som vi fortrænger, forbinder med noget truende eller opfatter som værdiløse. Heterologien peger dermed på en række generelle eksklusionsmekanismer på både et individuelt og samfundsmæssigt plan og søger genetableringen af det moderne menneskes relation til tilværelsens ikke-ideale og udsondrede aspekter, den såkaldt laverestående heterogene sfære: ${ }^{\mathrm{I}}$

"Det drejer sig om alt det, som det homogene samfund forkaster som affald [...]. Det er de produkter, der udskilles af kroppen og visse lignende materier (snavs, utøj mv.); de dele af kroppen, de personer, ord eller handlinger, der har en suggestiv erotisk værdi; forskellige ubevidste processer som drømme og neuroser; det store antal sociale elementer eller former, som den homogene del er ude af stand til at assimilere.” (Bataille, "Fascismens psykologiske struktur” I4)

Det homogene og heterogene kan forstås som et komplementært forhold, hvor det homogene repræsenterer samfundets produktive del, mens det heterogene kort kan beskrives som det, der falder uden for det rationelle samfunds målbare og opbyggelige idealer. Den homogene sfære forsøger følgelig at beskytte sin forskelsløse enhed ved at ekskludere de unyttige elementer og nedsætte forbud imod den heterogene sfære. De lavere sociale lag, den syge krop og den faldefærdige bydel omgærdes af forestillinger om smitte og fare og afgrænses fra den almindelige verden. Med dette kontaktforbud opnår heterogeniteten sin status som radikalt anderledes med negativt fortegn: de "elendige klasser" og "forfaldets kvalmende former vækker en så utålelig følelse af væmmelse, at det er forkert at tale om eller blot hentyde til dem" (Bataille, "Fascismens psykologiske struktur" I6).

I det vestlige samfund er eksklusionen af det heterogene imidlertid blevet totalitær, hvorfor der ifølge Bataille er behov for en balanceskabende praksis. Filosofien om det radikalt anderledes peger derfor på vigtigheden af, at den homogene normaltilstand med passende mellemrum udfordres - f.eks. ved udforskning af den heterogene andethed. Heterologien kan derfor anvendes som indgangsvinkel til at afsøge eventuelle potentialer i overskridelsen af det velkendte og tilegnelsen af det fremmede. 


\section{Det heterogene som urbant tema}

Baggrunden for at anvende det heterogene som æstetisk og urban term tager afsæt i Batailles opgør med det homogene samfunds idealiserede former gennem begrebet om det formløse: ${ }^{2}$

"formløs [er] ikke kun et adjektiv, der har en bestemt betydning, men et begreb, der tjener til at nedklassificere det, som normalt kræver, at hver ting har sin form. Hvad det betegner, har ingen rettigheder i nogen forstand og får sig selv knust overalt, som en edderkop eller en regnorm." (Bataille, "Informe" 5) 3

Det formløse beskriver en forskydende operation og et gradvist skred mod et lavere stadie, der opløser de faste betydningssystemer og åbner op for nye betydningsmæssige mutationer. Det er begrebet om det begrebsundvigende - et paradoks, der peger på det heterogene som et formundvigende procesbegreb, der søger at nedbryde enhver afsluttet definition og fast struktur. Det formløse åbner dermed op for et æstetisk brud med de stabile og ideale formers suverænitet og en urbanitetsæstetisk forskydning mod arkitekturen som muterende proces, sammenbrud og antiform.

Med det formløse som samlende betegnelse for det radikalt anderledes kan man således begynde at nærme sig en heterogen stedskarakteristik og antyde omridset af et heterogent bylandskab. Analysen af Nordhavn som heterogent byrum vil derfor tage udgangspunkt i følgende fire temaer:

\section{Ekskluderede steder}

Det heterogene betegner noget marginalt og grænsebetonet, der befinder sig konkret i byrummet, men samtidig adskiller sig fra det etablerede samfund. Dette sted er ladet med en særlig kraft og rangerer under kontaktforbuddet, idet det både konkret og alment påminder om noget urent og fremmed. Det heterogene byrum har derfor en betydelig liminal karakter, da subjektet her overskrider samfundets traditionelle grænser for senere at blive integreret på ny. ${ }^{4}$

I Det heterogene består både af en høj og en lav dimension. Da det imidlertid er den lave heterogenitet, som er relevant i forhold til denne læsning, da det er den lave del, som udgør et fremmedartet alternativ til homogeniteten, svarer min brug af heterogenitetsbegrebet derfor til Batailles definition på "den underlegne del" af den heterogene region (Bataille,

"Fascismens psykologiske struktur" 17).

2 Jeg placerer mig således i forlængelse af nyere amerikansk kunstteori og aktuel dansk byplanteori, hvor
Batailles begreb om det formløse anvendes som alternativ tilgang til arkitekturen, kunsthistorien og den moderne bys overskudsrum (Hollier; Bois og Krauss; Nielsen).

3 Min oversættelse.

4 Begrebet liminalitet er i udgangspunktet antropologisk og betegner de kulturelle overgangsperioder, hvor et individ skifter status ved at gennemgå en midlertidig, social marginalisering (Turner 36). 


\section{Monstrøse former}

Det monstrøse udtrykker noget amorft, der afviger fra det standardiserede som unaturligt og uskønt. Da arkitekturens og kroppens idealer hænger uløseligt sammen i Batailles begrebsverden, åbner det monstrøse således op for et æstetisk alternativ, der i modsætning til den monumentale arkitekturs idealisering af den vertikale og velproportionerede menneskekrop forherliger monstrets regelløse udskejelser. ${ }^{5}$ Bataille beskriver endvidere erfaringen af det monstrøse som et sansevækkende ubehag knyttet til dyb fascination og forførelse - en "udæskende usømmelighed, en smule komisk, men så meget mere kvalmende" (Bataille, "Naturens udskejelser" I57).

\section{Det cestetiske chok}

I forlængelse heraf knytter det heterogene an til en række urovækkende steder, og hvad Bataille betegner som "chokkets virkelighed" (Bataille, "Fascismens psykologiske struktur" I5). Der er med andre ord tale om ikke-hjemlige rum, som har en stærk indvirkning på subjektet og kulturelt opfattes som fremmede i betydningen af noget angstfuldt og katastrofalt. Det kendetegnende ved disse urovækkende steder er, at Bataille forbinder chokket med en ekstatisk energi, der fremkalder oplevelsen af en "angstvækkende glæde" (Bataille, "Landskabet" 89). Det heterogene sted udtrykker derfor en række ligheder med det sublime landskab, hvor det æstetiske betones som destabiliserende og fremmedgørende oplevelser. ${ }^{6}$

\section{Entropiske processer}

Begrebet entropi kan beskrive heterogenitetens degressive processer og figurative opløsning.7 Det er den selvnedbrydende bevægelse mod uorden, snavs og formløshed, som ethvert materiale undergår, medmindre der opretholdes en konstant energitilførsel. Entropiens rumlige skred muliggør samtidig, at ethvert sted kan blive fundament for noget nyt: Entropien river formerne ud af deres egentlige tiltænkte funktion og muliggør derved betydningsdannelsen af noget nyt.

\section{Nordhavn som heterogent byrum}

Nordhavn er som havn allerede på forhånd koloniseret af en serie kulturelle og mentale billeder, der reproducerer forestillingen om havnen som liminal zone mellem noget velkendt og fremmed - en stereotyp, der både genfindes i fremstillingen af den klassiske skibshavn som omstigningsplads for eventyret og i opfattelsen af den moderne industrihavn som et demoraliseret og lovløst sted på kanten af samfundet (Carlberg og Møller Christensen 34).

Også bykortet fremhæver Nordhavn som et område, der afviger fra det øvrige København. I Kraks kort er grænsen mellem by og havn tydeliggjort ved Kalkbrænderihavnsgade, der som et bredt orange bånd markerer skiftet fra en velkendt til en mere vanskeligt tilgængelig byvirkelighed: På bysiden refererer gadenavnene 
til en hjemlig geografi, mens havnesidens vejnavne henviser til ukendte byer og fremmede steder som Baltikavej og Orient Plads (Krak I38).

Det mest iøjnefaldende ved kortets gengivelse af Nordhavn er imidlertid, at havnefronten formår at unddrage sig enhver detaljeret kortlægning. Hvor bybilledet gengives med en mangfoldighed af infrastrukturelle enkeltheder, fremstår havnen som en ukortlagt verden med sporadiske vejanvisninger og et minimum af bygningsmarkeringer. Krak betegner Nordhavns fremherskende gråtone med "Erhvervsområde", men den hvide farve på de yderste havnearealer gives der ingen forklaring på. Dele af Nordhavn falder hverken ind under de gængse bebyggelseskategorier eller landskabsdefinitioner og fremstår i stedet som uvirkelige ikkesteder. De farveløse felter markerer en negativ signatur, der igen synes at udtrykke noget ekskluderet og definitionsundvigende i forhold til den øvrige bys gennemdetaljerede univers. ${ }^{8}$

Nordhavns mentale og kartografiske landskaber introducerer således området som et heterogent felt i det københavnske byrum - en betragtning, der dog først og fremmest skal testes i den følgende byrumstypologi, der med udgangspunkt i begrebet om det heterogene byrum og Nordhavns særlige kendetegn, hvad angår bygningsformer, genstandssammenstillinger og landskabelighed, vil forsøge at indkredse Nordhavns heterogene kvaliteter.

\section{Den industrielle havneruin}

Når man kommer fra Københavns indre by, viser Nordhavn sig ved en gruppe sydvendte industribygninger, hvoraf de mest fremtrædende er to cylinderformede siloer, der rager højt op over det horisontale havnelandskab som to grå monolitter. Denne bygningstype - den funktionstømte og imposante industribygning - udgør stedets landmark og den forste karakteristiske type for Nordhavn.

På bagsiden ligger endnu et forladt industrikompleks i stor skala. Selvom denne bygningsgruppe er mindst lige så overvældende et vidnesbyrd om Nordhavns industrielle fortid, forekommer disse bagvedliggende siloer at være langt mere ikke-eksponerede og glemte. Med facader, der præges af tillukkede og ituslåede vinduer, lange løbespor af rust, graffiti og en svag aftegning af Dansk Landbrugs

5 Bataille tager helt grundlæggende afstand fra arkitekturen, da han betragter de arkitektoniske kompositioner som repræsentanter for det homogene samfunds matematiske overjeg. Udgangspunktet for den af Bataille så forhadte monumentale arkitektur skal imidlertid findes i de biologiske formers udvikling fra abe- til menneskeform (Bataille, "Arkitektur" 137).

6 I lighed med en heterogen observans udfordrer begrebet om det sublime det klassiske skønhedsideals harmoni ved at koble det æstetiske med noget uskønt, overmenneskeligt, ubegribeligt og angstfuldt. Det sublime er bl.a. forbundet med voldsomme landskabelige dimensioner, gentagelsesstrukturer, vidstrakte tomme flader, upolerede overflader og nøgne vægge (Burke I23).

7 Entropi er et begreb fra fysikken, der beskriver ethvert materiales energitab (Nielsen I5).

8 Selv en kortlægningsgigant som Google Maps farer vild på Nordhavnen (Google). 

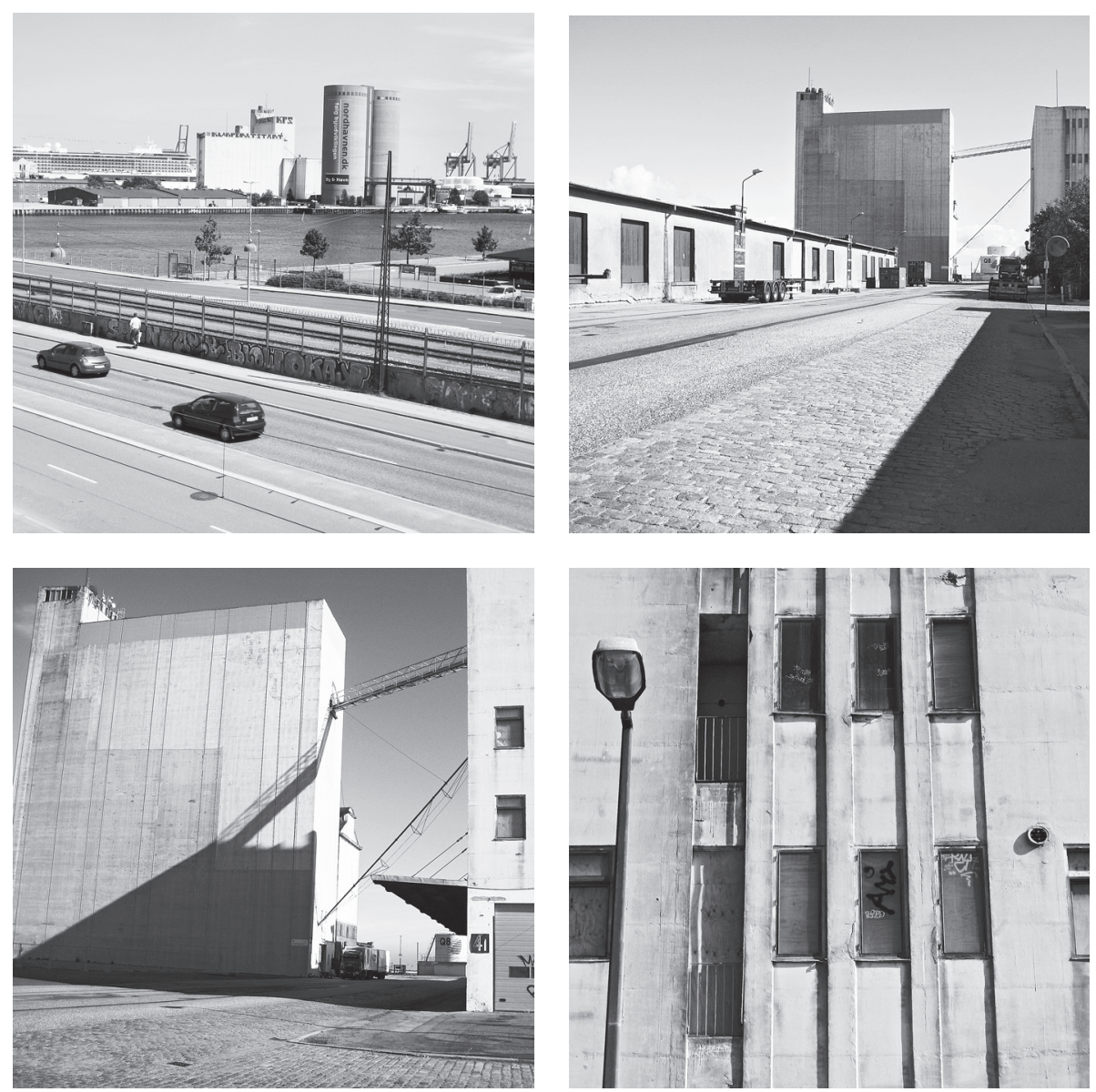

Fig. 1, 2, 3, 4 Heterogen type nr. I: Havneruinen.

(Foto: Helene Schytter)

Grovvareselskabs karakteristiske røde logo, udtrykker disse klassiske kornsiloer en overvældende ruinøs tristesse og mangfoldighed af entropiske spor, der gør den stejle jernbeton sanseligt historiefortællende. Farveskift i siloernes grå overflade afslører omridset fra tidligere, nu nedrevne tilbygninger, logoet fastholder stedets fortidige funktion, mens den snavsede slitage understreger anlæggets alder og forfald. Endelig udgør betonen baggrunden for et strukturelt skyggespil, hvor særligt den højtsvævende gangbro, som forbinder de to vinkelrette bygninger, aftegner sig forskudt som en grafisk gentagelse af de industrielle konstruktioner. Når man står på asfaltpladsen mellem siloernes rektangulære flader, er man således tilskuer til et historisk og arkitektonisk fravær, der udfolder sig på facaderne som et negativt drama på et tomt filmlærred. En urban scenografi, der på en poetisk og pågående 
facon fremkalder erindringen om havnearbejdsliv, maskinlarm, flaksende duer og korngods.

Nordhavns industribygninger repræsenterer dermed i udgangspunktet noget homogent, da disse fysiske strukturer er grundlagt med henblik på produktion og $ø$ konomisk vækst. Havnens homogene epoke som nytteorienteret arbejdszone er imidlertid ovre, og den funktionstømte industri udtrykker nu i stedet noget overvejende heterogent. Bygningerne befinder sig endnu langt fra den fuldstændige formløshed på en heterogen skala, men rummenes forfald trækker dem i en entropisk retning. Nordhavns industrianlæg udgør i den forstand en historisk ruin, hvori fortællingen om dansk industrialisme endnu lader sig spore. ${ }^{9}$

\section{Industrihavnen som cestetisk chok og kulturel fortrcengning}

Industrisiloernes heterogene karakter understreges, hvis man anlægger en historisk betragtningsvinkel på industribygningen, der i udgangspunktet forbindes med en irrationel og katastrofal kraft:

"Siden industrialismens begyndelse har disse steder været genstand for en fascination af samme dæmoniske art, som voldsomme naturfænomener - vulkanudbrud, jordskælv og tordenvejr - omfattes med. Den oplevelse af "undergang”, de formidler, kan hverken bortforklares eller forklares med rationelle argumenter, f.eks. under henvisning til deres nyttige funktion [...]. Måske skal dette industribillede snarere indkredses ved hjælp af psykoanalytiske kategorier.” (Sestoft I7)

Beskrivelsen af industribygningen som chokæstetisk og sublim fascination afspejler en grundlæggende fremmedgørelse, der kan forklares med henvisning til industriarkitekturens tekniske udvikling i det I9. århundrede. Med fremkomsten af nye materialer og bygningstyper opstår et fremmedartet arkitektonisk formsprog med rygende skorstene, blotlagte rørsystemer, en enorm skala, monotone flader og et fravær af ornament, der overskrider det arkitektonisk velkendte og udtrykker noget ikke-menneskeligt og maskinelt. Hertil kommer, at industriens bygninger aldrig for alvor anerkendes i bygningstypernes samlede hierarki, idet et bygningsværk som eksempelvis siloen per definition udgør noget planlægningsmæssigt og arkitekturhistorisk marginalt (Sestoft I3).

Denne sekundære position kendetegner $i$ et vist omfang stadig industriens bygninger i det 2I. århundrede, hvor marginaliseringen ikke længere gælder det industrielle byggeprojekt, men industriarkitekturen som bevaringsobjekt og dermed spørgsmålet om, hvorvidt industrialismen inkluderes i den kulturhistoriske

9 Da de to mest synlige siloer desuden bærer et gigantisk banner med henvisning til udviklingsselskabet By \& Havns website med påskriften "Nordhavnen.dk følg byudviklingen”, kan disse havneruiner endvidere ses som et liminalt rum, der på én gang henviser til et fortidigt, nutidigt og fremtidigt Nordhavn (By \& Havn A/S). 
fortælling. Mest udbredt er forestillingen om Danmark som landbrugsland, selvom vi i lige så høj grad har en fortid som rå, pulserende industrination (Jørgensen og Pedersen 6). Trods en stigende opmærksomhed på industriens kulturmiljømæssige kvaliteter, forbindes arbejdets bygninger stadig med noget værdiløst og fremmed, som "vi i dag [ikke] reagerer særlig negativt på [bliver] jævnet med jorden" (Kulturarvsstyrelsen). ${ }^{\text {IO }}$

Industriarkitekturen kan således forstås som et heterogent udtryk, der både på et materielt og mentalt plan indtager en lav og ekskluderet position i det arkitektur- og kulturhistoriske hierarki. Foruden at Nordhavns industribygninger i deres aktuelle ruintilstand besidder en række heterogene kvaliteter såsom entropi og chok, betoner det heterogene i denne sammenhæng derfor også et kulturhistorisk fortrængt aspekt og spørgsmålet om, hvordan vi i forbindelse med byens omdannelsesprocesser forholder os til det æstetisk modstandsgivende og de radikalt anderledes rum, vi vanskeligt identificerer os med.

\section{Havneskure og containerhybrider}

Efter siloerne bliver Nordhavns bebyggelse gradvist mere horisontal. Mindre værksteder, skurvogne og små havneskure skyder frem som en spatial underskov blandt de voluminøse industribygninger. Disse simple bygninger udgør den anden karakteristiske type for havnekulturmiljøet - en bygningsform, der fortættes og samler sig til en egentlig lille skurby: Fiskerihavnen.

Dette bric-á-brac-samfund er et særegent studie i skurarkitektur. ${ }^{I I}$ Nok finder man genkendelig fiskeriidyl i form af stokroser og garnruser, men Fiskerihavnen er langt mere end et forudsigeligt byrum og stillestående historisk tableau. De tætbyggede havneskure afspejler deres urbane beliggenhed og et tydeligt samspil med de industrielle omgivelser.

De fleste af skurene rummer reminiscenser af storby ved at være stablet i flere planer, så campingvogne og diverse bolighabitater udgør et improviseret etagebyggeri. Samtidig udtrykker facaderne, hvad man normalt vil forbinde med det klassiske skur: billige, uforarbejdede og forhåndenværende materialer såsom plastplader, pap og avispapir som isolering. Overalt ses overlejringer af tiloversblevne paller, byggeaffald, brudstykker af skibe og bunker af plader, rør og brædder fra tidligere byggeprojekter. Det særlige ved Fiskerihavnens knopskydende skurformationer er imidlertid, at Nordhavns allestedsnærværende ikon, containeren, udgør et

Io Netop Kulturarvsstyrelsens satsning i 2004-2007 på industrisamfundets kulturarv viste, at funktionstømte bygninger som f.eks. siloer og simple pakhuse har sværest ved at overleve, til trods for at netop disse strukturer er de mest karakteristiske for den industrielle erhvervshavn (Kulturarvsstyrelsen). Til gengæld er en genkendelig bygningstype som administrations- bygningen den bedst bevarede, da denne type er lettest at genanvende og i højere grad fortolkes som udtryk for høj arkitektonisk og æstetisk kvalitet (Schrøder 59).

II Skurbyggeriet kan bl.a. ses som en åben fortælling, der giver plads til betragterens egne forestillinger og fortolkninger (Hage og Møller 48-5I). 

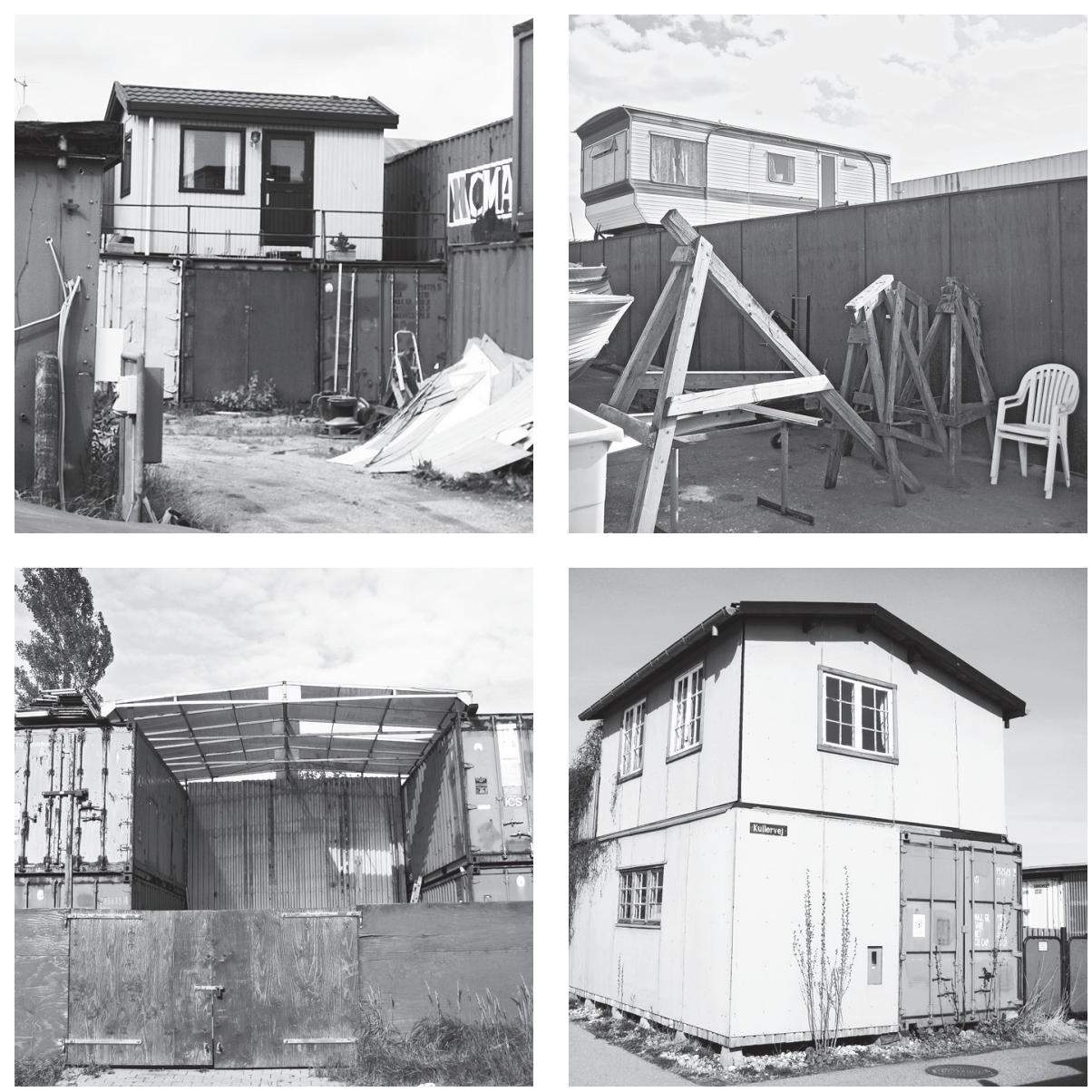

Fig. 5, 6, 7, 8. Heterogen type nr. 2: Havneskuret.

(Foto: Helene Schytter)

gennemgående rumskabende princip. I denne del af Nordhavn forskydes containerens funktion således til en bygningsmæssig sammenhæng, idet de farvestrålende jernkasser her indgår som alternative havneboligmoduler, der samtidig giver den traditionelle fiskeriidyl et industrielt og stedspecifikt twist.

Skurbyen er eksempel på et nordhavnsk (selv)byggeprincip, hvor skæve proportioner og et minimum af planlægning skaber et radikalt anderledes kulturmiljø, der samtidig udtrykker noget distinkt for havnen. Nordhavns skurhybrider kan således fortolkes som en monstrøs bastardarkitektur, hvor de simple materialers mutationer udfordrer de gængse æstetiske idealer og forskyder de sædvanlige materialesammenhænge. 


\section{Fiskerihavnen som alternativ proces-arkitektur}

Skuret indtager traditionelt set en lav placering i den europæiske arkitekturhistorie som noget ikke-arkitektonisk uden æstetisk appel: "Et cykelskur er en bygning. Lincolnkatedralen et stykke arkitektur” (Pevsner 15). Med I970’ernes afsøgning af nye eksperimentelle byggemåder udvides det æstetiske imidlertid til også at gælde ikke-ideale og oversete byggeformer som f.eks. skuret. Et eksempel herpå er de to danske arkitekter Carsten Hoff og Susanne Ussings mangeårige arbejde med en alternativ procesarkitektur, der lanceres som et generelt opgør med en monumental og helhedssøgende arkitekturtradition:

"Hvis fremtidens boligbyggeri skal gå ud på at åbne op for menneskers ånd og handlinger vil det forudsætte/medføre andre æstetiske normer, for der vil ikke være noget endeligt mål men en serie processer. [...] Andre nøgleord vil være sammensathed, mangfoldighed og foranderlighed. Den hårfine afstemning af materiale vil blive afløst af sammenstillinger af nye og brugte, og ydmyge materialer vil træde i stedet for de prangende.” (Hoff og Ussing I2)

I modsætning til masterplanens totaldesign arbejder Hoff og Ussings procesarkitektur med en række fleksible basismoduler, hvorfra boligstrukturerne udvikler sig spontant til uensartede bydannelser uden et på forhånd fastlagt forløb. Materialerne og deres gradvise kombination spiller en afgørende rolle i (u)bestemmelsen af de arkitektoniske former, da rumforløbet udelukkende betinges af en forhåndenværende og tilfældig materialesammensætning. Den æstetiske grundpræmis er således arkitekturen som ufærdig og morfologisk proces, hvor boligen udvikler sig i samspil med sine omgivelser og transformeres over tid. ${ }^{\mathrm{I} 2}$ Et princip, der ifølge de to arkitekter danner et varieret urbant udtryk, der modsat det traditionelle bybilledes forudsigelige strukturer sikrer et anderledes organisk bymiljø, hvor ingen gader eller pladser er ens. I forlængelse heraf udtrykker Nordhavns skurbyggerier et lignende procesprincip. Fiskerihavnens skævheder og additive byggeri skaber et tilsvarende brudfyldt byrum, der ikke udtrykker en samlet arkitektonisk vision, men formidler en flertydig arkitektonisk fortælling, der forgrener sig kontinuerligt i overensstemmelse med skurhybriderne og deres parasitære tilbygninger. Derudover udgør de mangfoldige variationer over containeren et godt eksempel på en fleksibel og åben struktur, der foruden at kunne (gen)bruges i utallige sammenhænge understreger noget morfologisk og identitetsgivende for stedet. Procesarkitekturen kan dermed ses som et konkret bud på en heterogen arkitektur, der tager udgangspunkt i det formløse som paradigme: En deform arkitektur, der ikke efterlever noget fast regelsæt og tager sig ud som en udefinerbar bastard.

I2 Et sådant morfologisk princip ses også i forbindelse med Christianias selvbyggerarkitektur, der i lighed med Hoff og Ussings procesarkitektur kan ses som udtryk for 1970'ernes afsøgning af nye byggemåder og ønske om at udvide det æstetiske felt (Hvilsby og Skov I32-I33). 

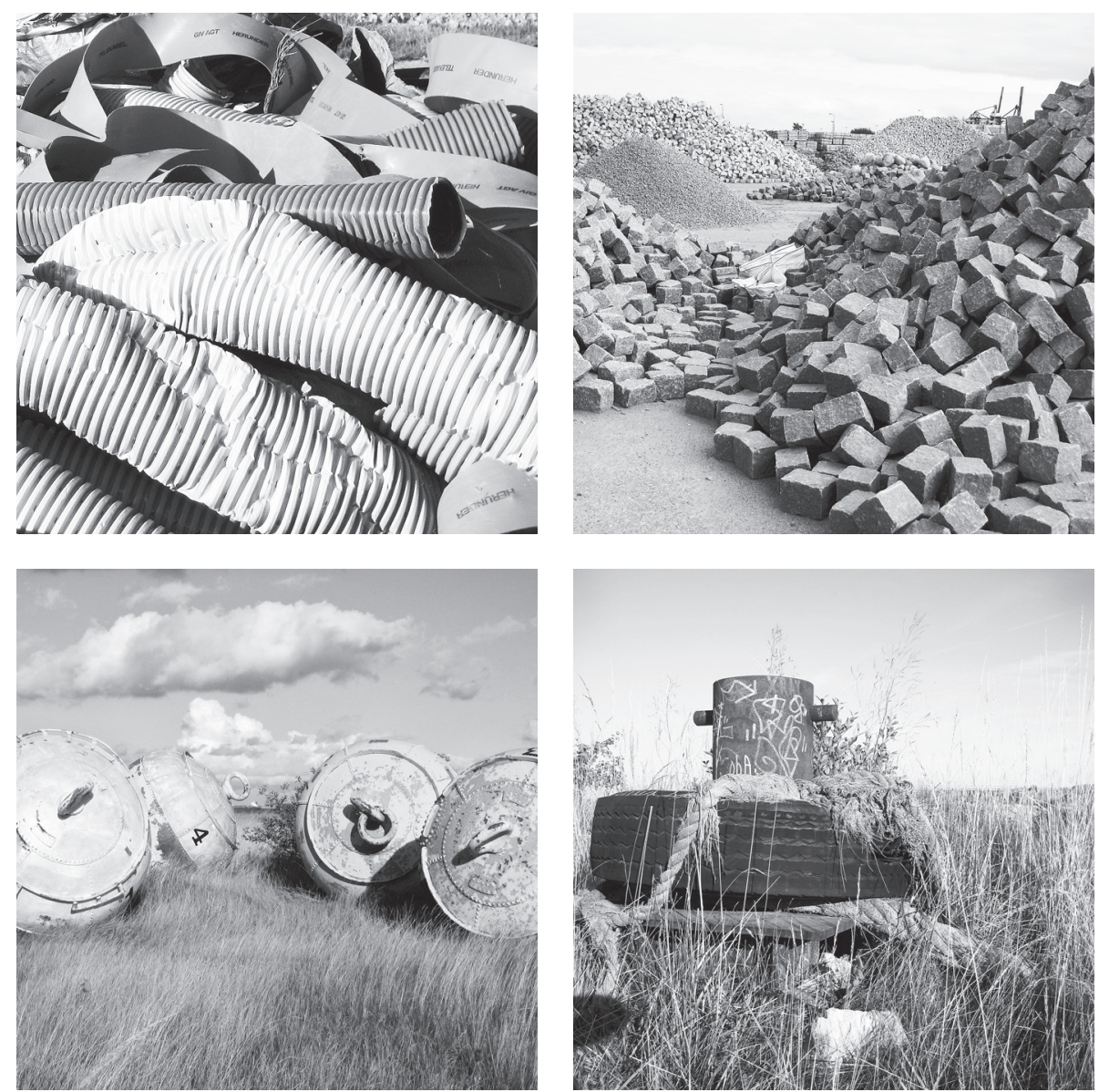

Fig. 9, 10, 11, 12. Heterogen type nr. 3: Havneskulpturen.

(Foto: Helene Schytter)

\section{Havnen som skulpturelt landskab}

Nordhavn byder også på mere undseelige registreringer af noget karakteriserende for havnelandskabet, og disse kendetegn tydeliggøres på bagsiden af Færgehavns Brygge og skurbyen.

Her begynder havnelandskabet for alvor at antage fremmedartede dimensioner med bulk- og skrotterminalernes sand- og skrotbunker. Dette ophobningsprincip, der til dels også kendetegner havnens containerstablinger, gentages i en lang række skulpturelle variationer. Et øde område viser sig at være et tætpakket skulpturelt landskab og et typologisk studie i aflagte objekter fra hele det resterende havneområde. Her er bjærgede bundgarnspæle, drivtømmer og meterhøje ankerbøjer, der ligger tungt i græsset som strandede undervandsgiganter. Et mangfoldigt los- 
sepladspræg af orange rør udgør en skulpturel improvisation over rillede plastikstrukturer, mens bunker af brædder og delvist sammentømrede skurfragmenter skaber en skulpturel reference til Fiskerihavnen.

Havnelandskabet rummer således en række skulpturelle træk, der enten består af sorterede stablinger af lavt forarbejdede eller udtjente objekter (sand, bildæk, skrot), enkeltstående fragmenter løsrevet fra deres oprindelige kontekst (fiskekutter, skurfragment, ankerbøje) eller kompositte størrelser af diverse havnerudimenter (rodebunker, plastikrør, affald). Selvom havnens restobjekter er udtryk for tilfældige formationer uden en bevidst kunstnerisk intention, rummer disse alligevel et æstetisk potentiale, der gør havnen til et privilegeret sted for skulpturelle betragtninger med heterogene kvaliteter.

\section{Selvudslettende monumenter og skulpturelle metamorfoser}

En oplagt indgangsvinkel til forståelse af havnelandskabets skulpturer er Robert Smithsons fotografiske ekskursion til Passaic i New Jersey i I967. I lighed med den funktionstømte havn rummer forstaden en række skulpturelle træk, som Smithson fortolker som en serie utilsigtede, entropiske monumenter over fysisk opløsning - en "selvudslettende postkortverden", hvor faldefærdige elementer, tomme parkeringspladser og ufuldstændige byggepladskonstruktioner varsler om enhver forms opløsning og fragmentation (Smithson 46). Kunstverdenens idealer forskydes hermed til et ikke-institutionelt felt, hvad der dels udvider skulpturbegrebet, dels afdækker et æstetisk potentiale ved byens bagsider.

På denne måde skitserer Smithson en monumenttype i lighed med Nordhavns formelle forfald. Ud fra en heterogen betragtning kan det aktuelle havnemiljø således forstås som et entropisk landskab, der giver indsigt i byens formløshed og forfaldsprocesser. Industrihavnens restskulpturer udtrykker noget kulturhistorisk fortrængt og en historie, der er godt på vej til at falde sammen, ruste væk og forsvinde for fremtiden. Nordhavn kan i den forstand forstås som en heterogen postkortverden, der i modsætning til en klassisk formidling af det historiske København giver indtryk af noget selvudslettende og midlertidigt monumentalt. ${ }^{\text {I3 }}$

Havnens skulpturelle variationer over et heterogent formsprog kan desuden betragtes ud fra ophobningen som moderne skulpturelt fænomen (Skytte 8). Hvor Smithsons entropibegreb beskriver de havnemonumenter, der udtrykker det formløse som gradvis opløsning, kan ophobningen karakterisere de kompositte havneobjekter og det modsatte aspekt af entropien: det formløse som tiltagende rodeprincip. Hvor første monumenttype forsvinder i takt med tiden, vokser ophobningen. Og hvor det selvudslettende monument bliver gradvist mere forskelsløst, forøges ophobningens materielle kontraster og sammenstød. Begge monumenttyper udtrykker imidlertid noget grundlæggende heterogent og åbner op for en række nye skulpturelle udtryk, der anviser en alternativ tilgang til det historiske og klassiske skulpturelle enhedsideal. 
På Nordhavn møder man aldrig de samme former - de forandres konstant - og visse steder er det tydeligt at se, hvordan forbipasserende interagerer i ophobningsprocessen ved at skabe nye kombinationer af de efterladte objekter. Havnens ophobninger tilbyder dermed en taktil og legende tilgang til det skulpturelle, idet de løsrevne materialer ansporer til en kreativ undersøgelse af de uendelige forandrings- og organiseringsmuligheder. Dermed aktiverer ophobningen også en dobbelt historisk erfaring, idet beskueren på den ene side genkender en række historiske spor fra det fortidige havnemiljø og på den anden side oplever, hvordan ophobningens foranderlige blandingsformer uundgåeligt skaber en række historisk ukorrekte nye relationer og betydninger (Skytte 46-47). De skulpturelle konglomerater udlægger således historien som en ikke-hierarkisk forandrings-, fortolknings- og konstruktionsproces, hvor det historieskrivende tyngdepunkt placeres $\mathrm{i}$ samtiden og hos subjektet. Nordhavns skulpturelle landskab udgør i den forstand et forskydende organiseringsprincip, der tildeler den forbipasserende en aktiv rolle - skulpturel så vel som historisk - i hvad man kunne kalde en heterogen kombinatorik og uafsluttet fortælling om havnen.

\section{Terrain-vague}

Vi er nu kommet til det yderste af Nordhavn, den fjerde type og Krakkortets hvide landskab: Et tomt terrain-vague, der hverken kan kategoriseres som natur, losseplads eller by. ${ }^{\mathrm{I}} 4$

Området bærer præg af naturovertaget ruinpark med et gigantisk bassin, et rustent slusesystem og tilhørende fabrikshal i stor skala med høje, nu tørlagte betonkanaler. Dette er resterne fra I990'ernes støbning og udslusning af de voluminøse elementer til Øresundsbroen. Mest imponerende er det yderste slusesystem, der som en rustrød ruin stadig holder vandet tilbage og via en sammenstyrtende, stejl trappe fører til et højtbeliggende udsigtspunkt. Heroppe fortsætter de entropiske jernmasser med et faldefærdigt trappesystem, der rejser sig flere meter over vandoverfladen og udgør en svimlende linedans over slusens afgrund. "Du drømmer om et andet sted”, står der med graffiti på broens indgangsparti, hvilket giver passagen over havnebassinet et ekstra rituelt præg, der ikke alene udfordrer kroppens balance, men også føjer et refleksivt niveau til den rumlige overskridelse.

Toppen af den forladte industrihavn føles unægtelig som et radikalt anderledes sted, hvor det er muligt at betragte hele Nordhavn og det resterende København fra

\footnotetext{
I3 Se også billedkunstneren Villy Ørskov, der i ligeledes i I960’erne afsøger byens bagside for skulpturelle mikroprocesser (Ørskov).

I4 Begrebet terrain-vague udtrykker noget undvigende, der falder uden for de traditionelle landskabskategorier, og kan med Villy Ørskovs definition meget præcist betegne, hvad jeg kalder byens heterogene bagside
}

med Nordhavnen som udgangspunkt: "Ligesom alle byer (af nogen alder) har deres pragtbygninger [...], deres 'stolthed', har de også deres 'skam', disse vage terræner [...], som er uden navne og betegnelser på bykortene. [...] Terrain-vague er derfor det sted (eller ikke-stedet), som byen vender ryggen til, et anti-miljø, antitesen til 'Rådhuspladsen”” (Ørskov I7-I8). 

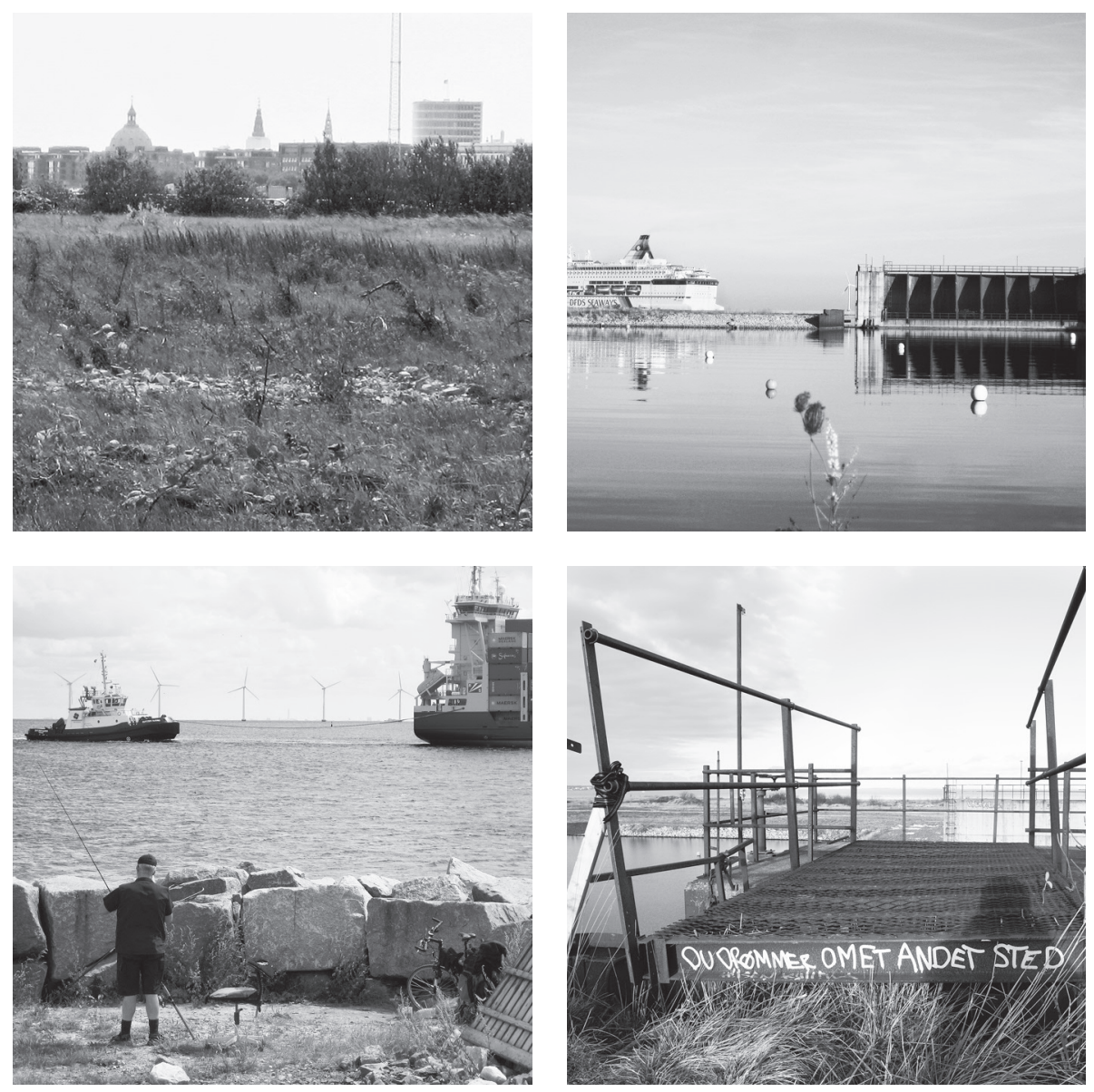

Fig. 13, 14, 15, 16. Heterogen type nr. 4: Terrain-Vague. (Foto: Helene Schytter)

en uvant vinkel. Refshaleøens fabrikshaller, som ellers ligger i den modsatte ende af byen, befinder sig overraskende tæet på - få hundrede meter på den anden side af vandet. Hvor industrien plejer at udgøre byens bagtæppe, udgør havnen nu forgrunden i det københavnske panorama. Et omvendt tableau, hvor havnearealernes funktionstømte landskab har trængt byens historiske centrum i baggrunden, mens de gigantiske container- og krydstogtskibe glider forbi som stedvise påmindelser om Nordhavns sidste havneaktivitet. Krydstogtskibenes hvide etager, der ligner hele byer, kunne faktisk minde om ikonografiske spejlinger af fremtidens Nordhavn og foregribe havnens transformation til boligområde. I det hele taget indbyder dette yderste Nordhavn til urban refleksion. "Hvor vil du helst bo?" spørger en anonym graffitimaler, alt imens Nordhavnstippen ligger udstrakt som et horisontalt ingenmandsland: Et liminalt og ekskluderet tomrum, der tilbyder en radikal landskabserfaring og et anderledes blik på det velkendte København. 


\section{Nordhavn som heterotopi}

Oplevelsen af et eksternt sted, der muliggør betragtningen af den etablerede orden fra nye vinkler, kan perspektiveres til Michel Foucaults begreb om heterotopien, der betegnes som:

" - virkelige steder, faktiske steder, steder som aftegnes ved selve samfundsdannelsen, og som er en slags mod-placeringer, en slags faktisk realiserede utopier, hvori de virkelige placeringer, alle de andre virkelige placeringer, som man kan finde inden for kulturen, på én gang er repræsenterede, anfægtede og omvendte, en slags steder som er uden for alle steder, også selvom de faktisk kan lokaliseres.” (Foucault 90)

Heterotopien kan forstås som en type rum, der på én gang udtrykker noget radikalt anderledes og samtidig reflekterer dets omgivelser. En form for andre rum, som på én gang anfægter og indgår i det etablerede samfund og således muliggør et på samme tid forskudt og fortættet billede af helheden. Heterotopiens spejling rummer derfor et vigtigt selvrefleksivt aspekt med liminale kvaliteter, da samfundet og subjektet her oplever sig selv i vekselvirkningen mellem et faktisk, historisk rum og en irreel, legende uvirkelighed, hvad der foruden at aktivere forestillingsevnen tilskynder jeget til at rekonstituere sig selv og sit sted.

Nordhavns funktionstomme landskab kan i forlængelse heraf fortolkes som stedet for en heterotopisk spejling og omvending af det velkendte København. En modplacering, der giver os mulighed for at danne uventede sammenhænge og se byen i et nyt perspektiv. ${ }^{15}$

Foruden dette urbane refleksionspotentiale udgør det nordhavnske terrainvague stedet for en række alternative praksisformer på et konkret plan. Nordhavns ingen- og allemandsland benyttes bl.a. af folk, der griller, fotograferer, fisker, lufter hund, laver graffiti, bygger svedehytter, kravler over hegn, overnatter, går ture, drikker øl osv. I modsætning til hvad man kunne kalde den homogene offentligheds kontrollerede og kapitaliserede byrum kan havnens betydningstømte wasteland forstås som et alternativt offentligt rum, der tiltrækker en række aktiviteter af umiddelbar hverdagslig, rekreativ eller marginaliseret karakter. Byens bagsider muliggør med andre ord en række af de urbane begivenheds- og subkulturer, som i stadigt stigende grad har vanskeligt ved at passe ind i byrummets kontrollerede scenografi, og som ud fra et homogent samfundssynspunkt opfattes som forstyrrende og fremmede. ${ }^{16}$ Fra en heterogen betragtningsvinkel kan samme praksisser

I5 Den spanske arkitekt Solá-Morales betragter byens ekskluderede tomrum som genspejlinger af det moderne subjekts fortrængninger og fremmedgjorthed over for byen, den Anden og sig selv. Ifølge Solá-Morales rummer byens terrain-vague derfor også et selvrefleksivt potentiale, idet subjektet her erfarer det fremmede på et alment materialiseret plan (SoláMorales I20).

I6 Se også Tom Nielsens betragtninger om overskudslandskabets alternative forbrug (Nielsen 99-IO8). 
imidlertid fortolkes som et positivt urbant engagement, der bidrager til det offentlige bylivs mangfoldighed og etableringen af nye urbane paradigmer. ${ }^{17}$

Det yderste Nordhavn kan således forstås som et ikke-defineret byrum, der opfordrer til udforskningen af noget urbant marginalt og udfordrer vores forestillinger om den velkendte by.

\section{Den heterogene som planlagningsparameter?}

Nordhavn byder i vid udstrækning på en radikalt anderledes urban oplevelse på både et rumligt, refleksivt og sociokulturelt plan. Selvom der umiddelbart er stor forskel på typerne ruin, skur, skulptur og terrain-vague, udtrykker disse en æstetisk og kulturel andethed, der udfordrer byens homogene idealer og tilbyder en heterogen identifikation. Samtidig kan havnetypologien ses som fire variationer over temaerne eksklusion, monstrøsitet, chok og entropi, der tilsammen danner en heterogen skala. Bevægelsen over Nordhavn beskriver en trinvis erfaring af det formløse, hvor industriarkitekturen udtrykker et minimum, mens havneskuret, de skulpturelle rester og terrain-vague-landskabet i stigende grad afspejler noget formafvigende, selvudslettende, betydningsforskydende og amorft.

I forlængelse af diskussionen om den værdiplurale by kan det heterogene således i første omgang betragtes som en urbanistisk praksis, hvor det heterogene potentiale består i selve erfaringen af det heterogene sted, overskridelsen af det velkendte byrum og bevidstgørelsen om det urbane systems dynamik (Nielsen 196). Omvendt åbner det såkaldte paradigmeskifte ${ }^{18}$ op for at medtænke det uformelle og uforudsigelige i den formelle byplanlægning og således tillade en højere grad af vekselvirkning mellem det heterogene og homogene. Midlertidige byrum, lowbudget-bevaring, æstetisering af funktionstømte bygninger samt additive byggeprocesser er alle eksempler på en planlægning, der udfordrer den rationelle bys æstetiske hierarkier, tilgodeser et minimum af renovering, inkluderer foranderlighed som et aktiv i byudvikling, og som dermed giver mulighed for et varieret byrum med heterogent tilsnit. ${ }^{\text {I9 }}$

I en postindustriel kontekst med homogeniserede havnefronter på stribe kan en heterogen analyse med blik for byens heterogene rum- og livskvaliteter således indgå i den kulturelle byudvikling ved at udpege kvaliteterne ved de byområder,

I7 Subkulturelle aktiviteter som skateboarding, graffiti og "urban exploration" er netop kendetegnet ved en direkte fysisk og æstetisk udforskning og overskridelse af byrummets velkendte grænser og kan desuden betragtes som en essentiel del af storbylivets forskellighed og urbane dynamik (Sennett I44-I5I).

I8 Jeg henviser her til arkitekt Peter Schultz Jørgensens term, da denne sammenfatter tendensen til at revurdere det æstetiske planlægningsparadigme og medtænke det fremmede i det kendte, sådan som eksem- pelvis det Realdania-finansierede udviklingsprojekt "Byens rum" lancerer (Jørgensen 38-48).

I9 Disse strategier understreger byudvikling som en ufærdig, åben og kontinuerlig proces med genbrug af bygninger af forskellig æstetiske standarder, en revurdering af de æstetiske hierarkier samt midlertidig og varig anvendelse af ikke-istandsatte og ikke-pæne bygninger til kulturelle og brugerinddragende formål (Jørgensen 38-48; Pløger 52-62; Carlberg og Christensen 48-6I). 
der står i udviklingsmæssig venteposition, og understrege det formløse som en modstandsgivende og æstetisk planlægningsfaktor, der gør byen til en sanselig og usamtidig oplevelse.

\section{LITTERATURHENVISNINGER}

Bataille, Georges. “Arkitektur.” Den Hovedløse - Batailles kosmologi. Red. Birgit Højgård Jensen. Århus: Forlaget Anis, 1984. 136-I38.

Bataille, Georges. "Landskabet.” Den Hovedløse - Batailles kosmologi. Red. Birgit Højgård Jensen. Århus: Forlaget Anis, 1984. 88-89.

Bataille, Georges. "Naturens udskejelser." Den Hovedløse - Batailles kosmologi. Red. Birgit Højgård Jensen. Århus: Forlaget Anis, 1984. 156-158.

Bataille, Georges. "Fascismens psykologiske struktur." Excesser. Om Georges Bataille. Red. René Rasmussen \& Asger Sørensen. Århus: Modtryk, 1994. 9-34.

Bataille, Georges. "Informe.” Citeret i Bois, Yve-Allain og Rosalind Krauss: Formless. A User's Guide. New York: Zone Books, I997. 5.

Bataille, Georges. "The Use Value of D.A.F. De Sade.” Visions of Excess. Red. Allan Stoekl. Minneapolis:

University of Minnesota Press, 2006. 9I-IO2.

Bois, Yve-Allain og Rosalind Krauss. Formless. A User's Guide. New York: Zone Books, 1997.

Burke, Edmund. A Philosophical Enquiry into the Sublime and Beautyful. New York: Routledge, 2008.

By \& Havn A/S. http://www.byoghavn.dk.

Carlberg, Nicolai og Søren Møller Christensen. Byliv og havnefront. København: Museum Tusculanums Forlag, 2005.

Christensen, René Schrøder. “Danske erhvervshavne I840-I970.” Den jyske Historiker I2I-I22 (2009): 43-62.

Foucault, Michel. "Andre rum.” Slagmark nr. 27. Århus: Modtryk, I997.

Google. http://maps.google.dk/Nordhavn.

Hage, Johan og Jesper Møller. "Planlægningsutopi og skrøbelig oase - rejse på Nordhavnens halvø.” Hovedstaden 2-3, (200I): 48-5I.

Hoff, Carsten og Susanne Ussing. Huse for mennesker. Om organisk byggeri. København: Forlaget Beboertryk, 1977 .

Hollier, Dennis. Against Architecture. Cambridge: MIT Press, 1992.

Hvilsby, Søren Holm og Pernille Skov. "Christianias skurvognsmorfologier.” Forankring i forandring. Christiania og bevaring som ressource i byomdannelse. Red. Svava Riesto. Århus: Arkitektens Forlag, 2007. I2I-I5I.

Jacobsen, Lise Skytte: Ophobninger. Moderne skulpturelle fanomener. København: Forlaget politisk revy, 2005 .

Jørgensen, Casper og Morten Pedersen. "Indledning." Den jyske Historiker I2I-I22 (2009): 5-I4.

Jørgensen, Peter Schultz. "Den foranderlige by." Kulturplaner - fra velfardsplanlagning til kulturel byudvikling. Red. Jan Bruun Jensen. København: Forlaget BOGVÆRKET, 2008. 38-48.

KRAK. Kraks minikort København 2009. København: Eniro Danmark A/S, 2008. 
Kulturarvsstyrelsen. http://www.kulturarv.dk/kulturarv/industrisamfundet.

Nielsen, Tom. Formløs. Den moderne bys overskudslandskaber. Århus: Arkitektskolens Forlag, $200 \mathrm{I}$

Pevsner, Nicolaus. Europas arkitekturhistorie. København: Politikens Forlag A/S, I97I.

Pløger, John. "Midlertidige byrum." Byens rum I - Det fremmede i det kendte. Red. Helle Juul. København:

Arkitekturforlaget B, 2008. 52-62.

Sennett, Richard. "Et samfund hvor man ser hinanden." Byens rum I - Det fremmede i det kendte. Red.

Helle Juul. København: Arkitekturforlaget B, 2008. I44-I5I.

Sestoft, Jørgen. Danmarks arkitektur. Arbejdets bygninger. København: Gyldendal, I979.

Smithson, Robert. A Tour of the Monuments of Passaic. Los Angeles: University of California Press, 1996.

Solá-Morales, Ignasi de. “Terrain Vague.” Anyplace. Red. Cynthia C. Davidson. New York: Anyone

Corporation, I995. II8-I23.

Turner, Victor. "Variations on the theme of liminality." Secular Ritual. Red. Sally F. Moore og Barbara G.

Myerhoff. Amsterdam: Van Gorcum, 1977. 36-52

Ørskov, Villy. Terrain-Vague. København: Borgen, 1992. 